\title{
Analysis of Taxi Transportation in Tourist Centres
}

\author{
Davor Brčića, Marko Slavulja, Dino Šojata ${ }^{a}$, Božo Radulovića \\ ${ }^{a}$ Full professor, Faculty of Transport and Traffic Sciences, Zagreb, Croatia
}

\begin{tabular}{|c|c|}
\hline ARTICLE INFO & A B STRACT \\
\hline $\begin{array}{l}\text { DOI: } 10.31075 / \text { PIS.66.01.03 } \\
\text { Professional paper } \\
\text { Received: 28.12.2019. } \\
\text { Accepted: 14.02.2020. } \\
\text { Corresponding author: } \\
\text { bradulovic@fpz.hr } \\
\text { Keywords: } \\
\text { Urban traffic } \\
\text { Taxi } \\
\text { Transportation } \\
\text { Liberalization } \\
\text { Dubrovnik } \\
\text { Split }\end{array}$ & $\begin{array}{l}\text { The liberalization of the taxi market in } 2018 \text { in the Republic of Croatia has resulted } \\
\text { in an increase in the number of taxi vehicles on the roads. In coastal tourist } \\
\text { centres, the demand for taxi transportation increases during the summer months. } \\
\text { In order to meet the transport demand, taxi carriers with licenses have arrived } \\
\text { from the continental cities to coastal cities. The paper will investigate the extent } \\
\text { to which continental taxis affect congestion and the overall structure of the traffic } \\
\text { flow. The purpose of the paper is to define a methodology for calculating the share } \\
\text { of taxi vehicles in the traffic flow, which will allow their distinction according to } \\
\text { registration marks. The aim of this study is to examine the proportion of vehicles } \\
\text { with non-domiciled plates in the centres of the tourist cities of Dubrovnik and Split. }\end{array}$ \\
\hline
\end{tabular}

\section{INTRODUCTION}

The liberalization of the taxi market in the Republic of Croatia has resulted in a rapid increase in the number of taxi vehicles on the roads. The effect of a large number of taxi vehicles is particularly evident in coastal cities during the tourist season, when demand for taxi services is extremely high. Due to the increased demand for a transport service, part of the taxi drivers from the continental part of Croatia decided to provide a transport service in the coastal cities. The result is directly reflected in the newly generated traffic flow. The aim of this paper is to investigate the share of taxi vehicles in the total traffic flow, as well as the share of taxi vehicles of continental license plates providing transportation services in the coastal cities. The research was conducted in two cities, Split and Dubrovnik, and the paper presents the research methodology, generalized results, discussion and conclusion.

\section{METODOLOGY}

In the study of traffic flow structure, the method of counting was used. Counting is a methodological procedure that determines the number of elements or members of a set. In this case the elements or members of a set are defined groups of vehicles.
Consequently, the traffic flow structure is divided into eight groups of vehicles, namely:

1. City bus - public transport;

2. Tourist bus;

3. Passenger car;

4. Taxi (domestic registration plates);

5. Taxi (other registration plates);

6. Motorcycle / moped;

7. Van (cargo and passenger);

8. Truck / heavy vehicle.

The counting was done manually at the cross sections of selected roads. In total, ten counting locations were selected, six in the city of Split, and four locations in Dubrovnik. Counting was done in the morning and afternoon peak periods.

Vehicle flow $q$ (vehicle / h) is the number of vehicles passing through a cross section of a road or one lane in a unit of time. By its structure, the traffic flow can be homogeneous or mixed. A homogeneous flow is considered to be a flow of a type of motor vehicle composed of vehicles of the same or similar technical characteristics. Thus, traffic flow can be: freight, passenger, special and other vehicles. [7]

A mixed flow is considered to be a traffic flow consisting of several types of vehicles. In practice, the heterogeneity of such a flow is represented by the percentage of other vehicles (buses, trucks, motorcycles, etc.) in the traffic flow. [2] 
$P_{\text {taxiDom }}=\frac{\sum q-q_{\text {bus }}-q_{\text {car }}-q_{\text {mo }}-q_{h v}-q_{\text {van }}-q_{\text {taxiOTHER }}}{\sum q} * 100[\%]$ (formula 1), where:

$P_{\text {taxiDom }}$ - share of taxi vehicles of domestic registration plates;

$\sum q$ - the sum of all vehicles in the traffic flow;

$q_{\text {bus }}$ - number of buses in the traffic flow;

$q_{\text {car }}$ - number of passenger cars in the traffic flow;

$q_{m o}$ - number of motorcycles/mopeds in the traffic flow;

$q_{h v}$ - number of heavy vehicles in the traffic flow;

$q_{v a n}$ - number of vans in the traffic flow;

$q_{\text {taxiотHER }}$ - number of taxi vehicles of other registration plates.

$P_{\text {taxiOTHER }}=\frac{\sum q-q_{\text {bus }}-q_{c a r}-q_{m o}-q_{h v}-q_{v a n}-q_{\text {taxiDOM }}}{\sum q} * 100[\%]$

(formula 2), where:

$P_{\text {taxiother }}$ - share of taxi vehicles of domestic registration plates;

$\sum q$ - the sum of all vehicles in the traffic flow;

$q_{\text {bus }}$ - number of buses in the traffic flow;

$q_{c a r}$ - number of passenger cars in the traffic flow;

$q_{m o}$ - number of motorcycles/mopeds in the traffic flow;

$q_{h v}$ - number of heavy vehicles in the traffic flow;

$q_{v a n}$ - number of vans in the traffic flow;

$q_{\text {taxiDom }}$ - number of taxis of domestic registration plates.

For the purposes of this research, formula (1) is defined to express the share of taxis with domestic registration plates in the traffic flow and formula (2) to determine the proportion of taxis that do not have the domestic registration plates. [3]

\section{RESEARCH RESULTS}

The collection of traffic data and its projections of traffic volumes are basic prerequisites for planning and managing road development schemes. [6]

Data were collected at a total of ten locations and averaged data were presented for more convenient presentation. Data were collected at a total of ten locations and averaged data were presented for more convenient presentation. Complete data can be accessed in studies [4] [5]. Traffic counting was conducted in two periods of the day, the morning and afternoon peak periods. Figure 1 and Figure 2 show the share of each vehicle type in the total traffic flow for the city of Dubrovnik and Split during the observation period.

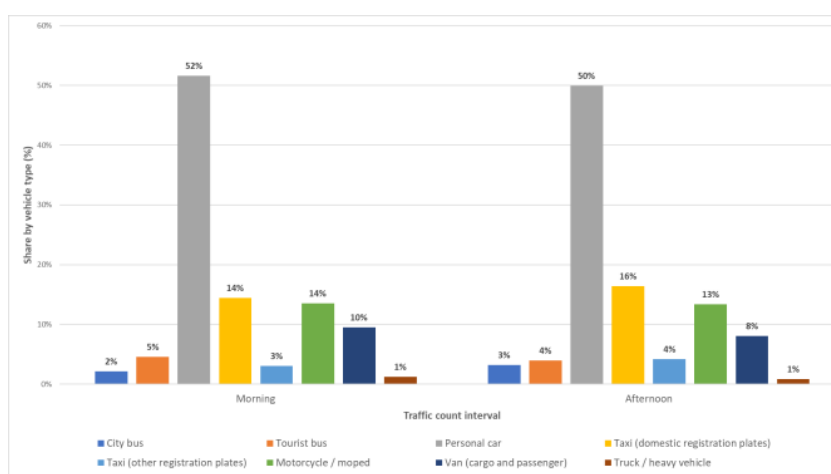

Figure 1. Share of vehicles by type, City of Dubrovnik Source: [5]

According to data obtained from a field research in the City of Dubrovnik (Figure 1), passenger cars account for the largest share of vehicles in traffic, with a share of $50 \%$ in the morning and $52 \%$ in the afternoon periods. This is followed by the share of taxi vehicles with $17 \%$ in the morning, of which $14 \%$ are domestic registration plates and $3 \%$ of other registration plates. In the afternoon, taxi vehicles represent a share of $20 \%$ of total traffic flow, of which $16 \%$ recorded taxis refer to taxis of domestic registration plates, while $4 \%$ referred to vehicles of other registration marks. Of other vehicles, motorcycles / mopeds have a higher share in the total traffic flow with a share of $14 \%$ in the morning and $13 \%$ in the afternoon, and vans with a share of $10 \%$ of the total traffic flow in the morning and $8 \%$ in the afternoon periods.

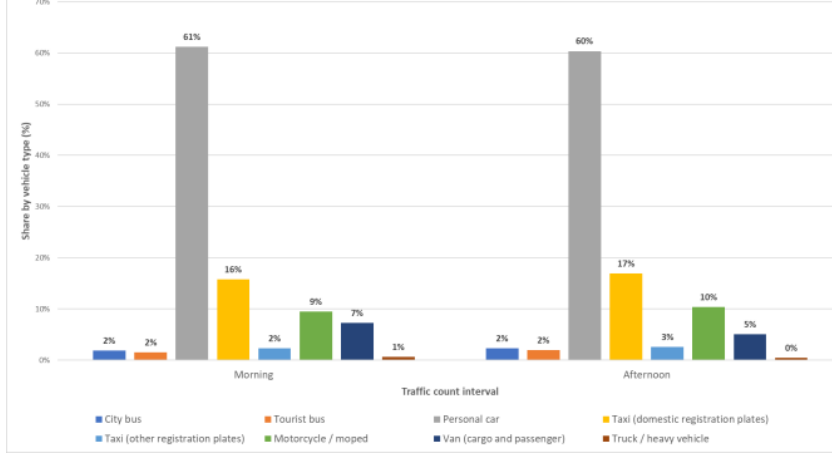

Figure 2. Share of vehicles by type, City of Split Source: [4]

Figure 2 shows the results of the field research in the city of Split. It is evident that passenger vehicles account for the largest share in the total traffic flow, with $61 \%$ in the morning and $60 \%$ in the afternoon periods. As in Dubrovnik, the second highest share of vehicles in Split is represented by taxi vehicles, with $18 \%(16 \%$ of domestic registration plates and $2 \%$ of other registration plates) in the morning observation period, while in the afternoon, the share of taxi vehicles increased to $20 \%$ ( $17 \%$ of domestic registration plates and $3 \%$ of other registration plates) of the total traffic flow. This is followed by motorcycles / mopeds with a share of $9 \%$ of the total traffic flow in the morning and $10 \%$ in the afternoon periods, and vans with a share of $7 \%$ of the total traffic flow in the morning and $5 \%$ in the afternoon periods. 


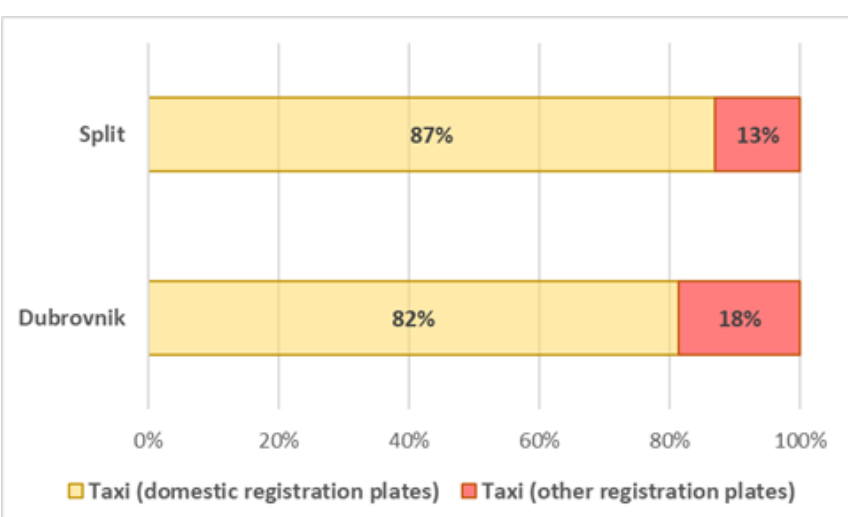

Figure 3. The share of taxis by registration plates, Source: [4] [5]

Observing the share of taxi vehicles according to vehicle registration marks, it was concluded that domestic taxi vehicles still represent a major proportion. The survey found that taxi vehicles of other license plates represent $18 \%$ of the total number of taxi vehicles in the city of Dubrovnik, while in Split the share is lower and amounts to only $13 \%$ of the total number or taxi vehicles in operation.

\section{DISCUSSION}

The data presented in this paper show the average results of all observed locations, and there are considerable discrepancies for certain locations. There are locations where the traffic flow with large differences in proportions when it comes to taxis is recorded, thus highlighting the location of "Ulica Domovinskog rata" in Split, where at peak time the share of taxi vehicles was as high as $40 \%$ (34\% of the domestic registration plates and $6 \%$ of other license plates), thus becoming the primary form of traffic in the city. There are also similar locations in Dubrovnik, an example of which is the "Pile" location, where the share of taxi vehicles in the peak hour reaches $34 \%$ of the total traffic flow, of which $28 \%$ are taxis of domestic registration plates, and $6 \%$ of taxis of other registration plates.

There is a great need for continuous monitoring and collection of traffic flows and other indicators of mobility. The reason for this is to obtain urban mobility trends that would result in better decision-making and urban policies for cities. [1]

\section{CONCLUSION}

Although there are concerns about the rapid increase in the number of taxi vehicles as a result of market liberalization and the arrival of a large number of taxi vehicles from the continental area of the Republic of Croatia to the coastal area for the purpose of providing transport services, this share still represents about $3 \%$ of the total traffic flow in the cities researched.
When viewed as a share of the number of taxi vehicles of other registration plates compared to domestic registration vehicles, the ratio continues to favor domestic taxis. The share of taxi vehicles with domestic registration plates in Dubrovnik represents $82 \%$, while in Split $87 \%$ of the total number of taxi vehicles, which concludes that a large number of taxi drivers coming from the continental territory of the Republic of Croatia is still not a critical segment in the total traffic flow, and therefore cannot be a main cause of traffic congestion in the observed areas.

It was concluded that future research should monitor the structure of traffic flow, as one of the important traffic indicators, on an annual basis, in order to enable comparison and quality decision-making in the direction of improving the urban transport system.

\section{References}

[1] Ceder, A. (2016). Public Transit Planning and Opertion, CRC Press. Taylor \& Francis Group. London.

[2] Dadić, I. (2007). Teorija i organizacija prometnih tokova. Fakultet prometnih znanosti Sveučilište u Zagrebu. Zagreb.

[3] European Metropolitan Transport Authorities (EMTA). (2006). EMTA barometer of Public Transport in European Metropolitan areas in 2006.

[4] Slavulj, M., Brčić, D., Šimunović, Lj., Ćosić, M., Šojat, D., Jurak, J., Radulović, B. and Sikirić, M. (2019). Istraživanje gradskog prometa u Gradu Splitu. Fakultet prometnih znanosti Sveučilište u Zagrebu, Zagreb.

[5] Slavulj, M., Brčić, D., Šimunović, Lj., Ćosić, M., Šojat, D., Jurak, J., Radulović, B. and Sikirić, M. (2019). Istraživanje gradskog prometa u Gradu Dubrovniku. Fakultet prometnih znanosti Sveučilište u Zagrebu. Zagreb.

[6] Walshon, B. and Pande, A. (2016). Traffic Engineering Handbook, 7th Edition (ITE), John Wiley and Sons Inc.

[7] Zakon o cestama (Narodne novine br. 84/11, 22/13, 54/13, 148/13, 92/14) 